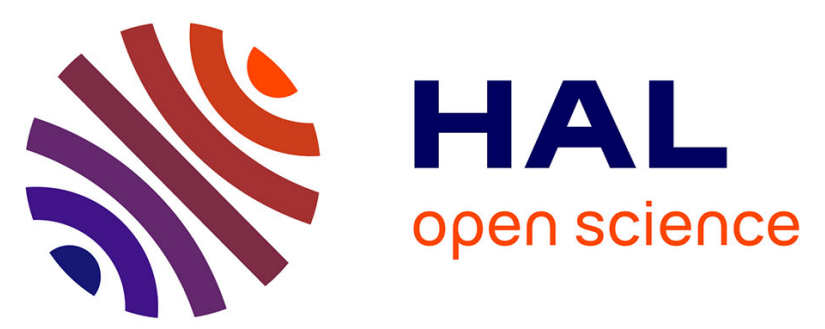

\title{
Sarah Bowen, 2015, Divided Spirits: Tequila, Mezcal, and The Politics of Production, University of California Press, Oakland, California, 256 p, ISBN 978-0-520-28,105-9
}

Philip H. Howard

\section{To cite this version:}

Philip H. Howard. Sarah Bowen, 2015, Divided Spirits: Tequila, Mezcal, and The Politics of Production, University of California Press, Oakland, California, 256 p, ISBN 978-0-520-28,105-9. Review of Agricultural, Food and Environmental Studies, 2016, 97 (4), pp.271-272. 10.1007/s41130-016-0029-y . hal-03114835

\section{HAL Id: hal-03114835 \\ https://hal.science/hal-03114835}

Submitted on 19 Jan 2021

HAL is a multi-disciplinary open access archive for the deposit and dissemination of scientific research documents, whether they are published or not. The documents may come from teaching and research institutions in France or abroad, or from public or private research centers.
L'archive ouverte pluridisciplinaire HAL, est destinée au dépôt et à la diffusion de documents scientifiques de niveau recherche, publiés ou non, émanant des établissements d'enseignement et de recherche français ou étrangers, des laboratoires publics ou privés. 


\title{
Sarah Bowen, 2015, Divided Spirits: Tequila, Mezcal, and The Politics of Production, University of California Press, Oakland, California, 256 p, ISBN 978-0-520-28,105-9
}

\author{
Philip H. Howard ${ }^{1}$
}

Published online: 2 December 2016

(C) INRA and Springer-Verlag France 2016

Geographic indications are increasingly promoted as a rural development strategy, including in less industrialized countries. Most of the evidence for their success, however, comes from the Group of Eight countries. This book examines the first geographic indication that was established outside of Europe, for alcoholic beverages made from agave plants in Mexico. It is based on a decade of fieldwork by the author, which included interviews at every stage of the supply chain-from agave farmers and farmworkers, to bartenders and retailers. She delivers a cautionary tale for those who propose to apply the European model to other parts of the world, as she concludes that few of the social or environmental aspirations that motivated them have been fulfilled in this case.

"Tequila" is a geographic indication established in 1974. It defines a spirit distilled from one species, blue agave, and is limited to producers operating within parts of five states in Mexico. "Mezcal" was a more generic term for spirits produced from other agave species, as well as wider geographic areas than tequila, but in 1994 it became limited to just five states. Bowen uses the term denomination of origin (DO) rather than geographic indications throughout the book, as her focus is on comparing tequila and mezcal to other cases where national governments play a large role in defining and enforcing standards - these include Comté cheese in France, which she has also studied in detail.

The differences between tequila, mezcal, and agave spirits produced outside of these DOs are fascinating, because as this

Philip H. Howard

howardp@msu.edu

1 Michigan State University, 480 Wilson RD, Rm 316, East Lansing, MI 48824, USA book clearly illustrates, they reflect differences in power. The industrial producers that dominated the tequila market (Cuervo and Sauza), for example, exerted significant influence over this indication, including limiting the geographic area and privileging industrial processes in the quality standards. Agave spirits have been produced in most regions in Mexico for approximately four centuries, and denominations of origin are supposed to protect cultural heritage and promote economic development-yet, the DO for mezcal was constrained to the areas where just three powerful groups had concentrated their agave growing, distilling, and bottling operations. In addition, the production standards are very similar to those of tequila, even though some factors are not defined appropriately for smaller-scale production. The maximum acidity level, for example, is frequently exceeded when fermentation rates are slower, which has forced many artisanal producers to change their entire production process. Because the most dominant firms in mezcal production are weaker than those in the tequila industry, however, small-scale producers have been more successful in advocating for changes. Some of these include adding parts of three more states to the DO for mezcal since it was implemented, and influencing a government proposal that would benefit smaller operations by adjusting the quality standards.

These power differentials may be less evident in Europe, where small producers have more organizational capacity, and rhetoric can more successfully obscure the real winners and losers. In Mexico, however, elite actors speak bluntly of taking advantage of minority ethnic groups and the poor. One of the most interesting examples in the book describes a failed effort in 2011 to restrict the word "agave" to existing denominations of origin, and even to prohibit labeling the percentage of agave used in production on the bottle. Bowen observes that this was one of the few instances where dominant distilling firms failed to achieve their policy goals, which was a 
result of organized pressure from a coalition between small producers in Mexico and retail/consumer groups in the USA.

Another intriguing aspect of tequila and mezcal supply chains is the rapidly increasing demand for these products in recent years, and like many other agricultural products, the difficulty in adjusting supplies is to keep pace. The power of the distillers is wielded here as well, as many have moved from buying agave on the market to long-term production contracts, or even greater levels of vertical integration through growing all of their own supplies. This in turn has contributed to agave monocultures, and increased susceptibility to pests and disease. Boom and bust cycles have reinforced these problems through their negative impacts on small-scale agave farmers, as low market prices have contributed to the neglect and abandonment of fields.

Although currently tiny in terms of sales, the fastest growing segment of the market is for artisanal mezcal, including spirits produced outside the boundaries of the DO. This trend is supporting more diverse agriculture and better economic outcomes - in some cases even encouraging migrant laborers in the USA to return to their villages in Oaxaca. As with other food trends, there is a very real risk that consumer's interest in "authenticity" will be successfully co-opted by dominant firms to help sell their industrial-scale products.

A minor critique of the book is one that unfortunately also applies to most social science research. After analyzing a litany of examples in which governments intervened to serve powerful interests, the author advocates more government actions to address these very inequalities. She describes exam- ples of cooperatives and other voluntary associations developing their own (i.e., non-governmental) standards to achieve positive outcomes, but they are not as seriously considered as strategies to achieve social and environmental goals. She does, however, give voice to opposing views, such as Daniel Pérez, an academic who says, "All of the cases of regulation of agave distillates in this country have been a mistake. Every time they standardize, they leave all the richness [of these distillates] outside the standards" (175). In addition, her conclusion emphasizes that many government policies beyond the realm of denominations of origin also reinforce existing problems, such as trade, labor, and immigration policies, both in Mexico and the USA.

The book is very well organized and clearly written. Bowen does an excellent job of including a rich amount of detail in a small amount of space. Quotes from informants are deftly employed, both to underscore her analysis and to make it livelier than a typical scholarly book. In addition, she includes many useful maps and photos to illustrate key steps in the production of tequila and mezcal.

The narrative also makes frequent connections to important themes and recent literature in the sociology of food and agriculture-some of these subjects include standards, culture, industrialization, globalization, labor issues, local knowledge, and rural development. I therefore highly recommend this book, not only to those who study geographic indications or other food standards, but to graduate students and researchers in the broader field of food studies as well. 